'Fundação Oswaldo Cruz (Fiocruz), Escola Nacional de Saúde Pública Sergio Arouca (Ensp) - Rio de Janeiro (RJ), Brasil. carlosbizarro@ensp.fiocruz. br

\section{Corpo e paradigma da imunização: reflexões sobre território, saúde e gênero a partir da metáfora do sangue}

\author{
Body and immunization paradigm: reflections on territory, health and \\ gender from the blood metaphor
}

Carlos Alberto Bizarro Rodrigues', Fermin Roland Schramm $\mathbf{1}$

DOI: 10.1590/0103-11042019S709

\begin{abstract}
RESUMO Este trabalho pretende contribuir para a reflexão sobre o corpo no desenvolvimento do EstadoNação entre o século XIX e o início do século XX tendo a metáfora do sangue como como chave heurística e referencial de análise. A escolha desse período se deu por sua importância política, econômica e social para os Estados Modernos. Nestes, os dispositivos biopolíticos e de biopoder, engendrados pelo paradigma da imunização e por intermédio das teorias higienistas e eugenistas misturadas à linguagem de germes e de genes, concorreram para que a noção de fronteira nacional ultrapassasse o limite territorial. Nesse entendimento, o Estado-Nação, visto por meio da metáfora do sangue, pode auxiliar a compreensão dos dispositivos biopolítico-imunitários na sua construção identitária. Tais dispositivos, agindo sobre os corpos, integraram-se à agenda nacionalista de algumas ex-colônias desde sua dimensão geográfica até o âmbito da vida privada. Nesse contexto, os discursos biomédico, científico, político e moral se confundiram, fundamentando um conjunto de comportamentos, crenças e saberes sobre o corpo e o território que cooperaram com seus projetos nacionalistas. Por fim, o objetivo deste artigo foi ilustrar, por meio da metáfora do sangue, que a polissemia do termo ‘sangue’ no discurso dominante do paradigma da imunização do final do século XIX e do início do século XX consolidava os debates sobre cidadania, naturalização e inclusão em países como Austrália, Estados Unidos e Brasil.
\end{abstract}

PALAVRAS-CHAVE Temas bioéticos. Corpo humano. Territorialidade. Saúde pública.

\begin{abstract}
This work intends to contribute to the reflection on the human body position in the development of the nation-state between the nineteenth and early twentieth centuries with the metaphor of blood as the heuristic and referential analysis key. This period was chosen because of its political, economic and social importance for the Modern States. In these, biopolitical and biopower devices, engendered by the paradigm of immunization and through hygienist and eugenic theories mixed with the language of germs and genes, contributed to the notion of national boundary crossing the territorial limit. In this understanding, the nation state, viewed through the metaphor of blood, can help the understanding of biopolitical-immune devices in their identity construction. Such devices, acting on the human bodies, were integrated into the nationalist agenda of some former colonies from their geographical dimension to the realm of private life. In this context, the biomedical, scientific, political and moral discourses were confused, supporting a set of behaviors, beliefs and knowledge about the human body and territory that cooperated with their nationalist projects. Finally, the aim of this paper was to illustrate, through the blood metaphor, that the polysemy of the term 'blood' in the dominant discourse of the late nineteenth and early twentieth century immunization paradigm consolidated the debates on citizenship, naturalization, and inclusion in countries such as Australia, the United States, and Brazil.
\end{abstract}

KEYWORDS Bioethics themes. Human body. Territoriality. Public health. 


\section{Introdução}

O desenvolvimento do Estado Moderno no Ocidente se deu acompanhado de uma reflexão política em termos biológicos, conhecida atualmente como biopolítica, pois a saúde do corpo se tornou assunto decisivo e demandou formas de controle, coordenação e integração da vida privada e dos coletivos humanos' ${ }^{1}$. As novas 'tecnologias de população' biopolíticas transformaram a dimensão orgânica em componente da gestão econômica, de modo que aspectos como a ociosidade e a utilidade, a suscetibilidade a doenças e o aprimoramento humano se vincularam à noção de corpo ${ }^{2}$.

A medicina, entendida mais como técnica geral de saúde do que como cura de doentes, favoreceu o controle social por meio de uma polícia médica que assegurava a ordem, o enriquecimento e a manutenção da saúde. Nesse contexto, o profissional médico ganhou status e se constituiu formador de modos de vida e de comportamentos. Como conselheiro governamental e autoridade biopolítica, sua tarefa passou a incluir a vigilância, a educação e a manutenção do corpo individual e social ${ }^{2}$. Assim, o biopoder propiciou a estatização da vida biológica ao confiar aos médicos o poder sobre a vida e sobre a morte dos indivíduos ${ }^{\mathbf{3}, 4}$.

Os processos de profundas transformações políticas não se restringiram aos países do continente europeu. De fato, simultaneamente às principais vertentes europeias da medicina social, os dispositivos biopolíticos e de biopoder se desenvolveram e influenciaram a estruturação das ex-colônias como nações, bem como criaram condições de possibilidade para a instauração do paradigma da imunização $0^{5}$. Neste, o conceito de imunidade reflete o poder de conservação da vida, tornando inseparável sua relação com a morte e com a política ${ }^{6}$, o que torna importante sua definição para a compreensão da biopolítica tanto na modernidade quanto no mundo contemporâneo.

O termo 'Paradigma da imunização' foi cunhado em 2004 pelo filósofo italiano Roberto Esposito em seu livro 'Bios: biopolítica e filosofia', no qual busca uma continuidade histórica entre o poder soberano e o biopoder do Antigo Regime com a biopolítica no Estado Moderno. Segundo ele, o vocábulo 'imunização' estabelece uma relação entre bíos (vida) e nómos (lei), que remete ao poder 'sobre e na vida'. Em outras palavras, a 'imunidade' se inscreveria na linha de tangência entre as dimensões da vida e do direito, visto que é uma palavra que não se refere somente à relação entre vida e poder, mas também ao poder de conservação da vida, pelo fato de que

não existe um poder externo à vida, assim como a vida nunca se dá fora das relações de poder. Vista dessa perspectiva, a política não é nada mais do que a possibilidade ou o instrumento de conservar viva a vida ${ }^{\mathbf{7 6 0}}$.

Vale ainda dizer que esse poder de conservação da vida tem um caráter de 'proteção negativa', isto é, um poder destrutivo subjacente ao poder conservativo da vida.

A imunização política, portanto, é uma espécie de proteção negativa da vida na qual a aparente oposição entre vida e morte é substituída por uma relação inclusiva e imanente, uma vez que a morte deixa de ser o limite externo e oposto à vida, tornando-se um de seus aspectos, mesmo que contrário a ela. Destarte, no paradigma da imunização, a vida tende a ser conservada; e a expressão do poder negativo e positivo encontra uma articulação interna ${ }^{6}$. Para Esposito, o poder negativo que se impõe sobre a vida não vem de fora, mas da forma intrinsecamente antinômica como a vida mesma se conserva por meio do poder.

Quanto ao desenvolvimento dos EstadosNação, o paradigma da imunização apresenta conexões com os saberes do campo da fisiologia e da patologia e na criação de metáforas biomédicas, sobretudo aquelas surgidas entre o século XIX e as primeiras décadas do século XX. Com efeito, a descoberta dos agentes etiológicos e do funcionamento do sistema imunológico no combate aos patógenos teve impacto na utilização dessas ideias no âmbito 
da ação política ${ }^{6}$ Isto é, a imunização política e social associava a ideia de imunidade à de proteção comunitária, o que fomentou a elaboração desse tipo de metáfora, particularmente aquelas associadas ao termo 'sangue', nas quais este trabalho pretende se debruçar.

Nesse mesmo período, a ciência da bacteriologia se voltava para o isolamento e erradicação patógena nos fluidos corporais. Apesar da transição das antigas teorias que atribuíam a causa das doenças aos miasmas ambientais para as bacteriológicas não ter sido imediata e suave, os cientistas médicos estavam convencidos de que a identificação dos microrganismos como a causa das doenças infecciosas os autorizava a buscar e a eliminar os germes. Essa preocupação com o corpo e com os seus 'segredos' foi dividida com os eugenistas que buscavam aquelas características hereditárias capazes de determinar os atributos humanos. A proximidade de interesses entre essas duas classes profissionais propiciou uma espécie de entrelaçamento entre as linguagens eugênica $e$ médica, o que promoveu a união desses saberes por meio das metáforas referentes ao sangue que fundamentaram e serviram de base para a tessitura de uma nova rede discursiva, responsável por produzir antinomias tais como nacional/estrangeiro, progresso/atraso etc. ${ }^{8}$. De fato, o termo 'sangue' apresentava uma polissemia própria que abrangia a imagem de carreador de germes e dos 'genes', ou seja, o discurso sobre o sangue, fundamentado em conhecimentos estatísticos, médicos e eugênicos, era o discurso dominante sobre a vida e consolidava os debates sobre cidadania, naturalização e inclusão no final do século $\mathrm{XIX}$ e nas primeiras décadas do século XX em nações como Austrália, Estados Unidos e Brasil. Portanto, o objetivo deste artigo é ilustrar a influência que a polissemia do termo 'sangue' teve no discurso produzido sob o paradigma da imunização por meio do artifício da metáfora do sangue e por intermédio de exemplos apontados pela literatura específica.

Quanto ao uso de metáforas para a compreensão do real, pode-se dizer que, embora não sejam capazes de substituir sua concretude, elas produzem a paisagem em que se assentam os estereótipos que moldaram a identidade nacional das ex-colônias. Em outras palavras, apesar de não terem a função de denotação e afirmação dos fatos, as metáforas iluminam o conhecimento e promovem uma melhor compreensão de um tema ao transferir um vocábulo de uma significação para outra9,10. Nesse sentido, nosso uso metafórico do termo 'sangue' se justifica pelo reconhecimento do corpo como objeto da biotecnociência, do biopoder e da biopolítica modernas, e sua apreensão como 'corpo próprio"11 ultrapassa a mera transposição metafórica entre o biológico, o biomédico e o político e revela seu lugar central nas intervenções médica e política modernas: é no corpo que política e biologia se unificam 5 .

\section{Corpo como fundamento biológico da ordem moral}

O corpo se tornou uma preocupação no Ocidente a partir do século XVIII, particularmente devido à biologia ${ }^{12}$. Com efeito, ele se tornou central em vários aspectos da vida civilizada e o fundamento biológico da ordem moral, substituindo a antiga ordem cósmica pela coerência biológica entre os sistemas ${ }^{13,14}$. Portanto, torna-se imprescindível esclarecer o que se entende como 'fundamento biológico da ordem moral' e sua correlação com a noção de incomensurabilidade dos sexos a fim de dar subsídios para a discussão a seguir. Em seu livro 'Inventando o sexo: corpo e gênero dos gregos a Freud', de 1992, o historiador norte-americano Thomas Laqueur afirma que a compreensão atual do que seja sexo surgiu em algum momento do século XVIII a partir das descobertas anatômicas que transformaram o corpo no alicerce do discurso social. Nesse movimento, a anatomia da mulher passou a servir de base para um novo fundamento do gênero, ou melhor, o corpo reprodutivo da mulher tornou-se o ponto de inflexão da redefinição da antiga relação social, íntima 
e fundamental entre homens e mulheres. De fato, as formas tradicionais complexas em que as semelhanças entre corpos, e entre corpos e o cosmo, confirmavam a ordem de um mundo hierarquicamente concebido foram reduzidas a um único plano, o da natureza. Desse modo, no mundo da explicação científica moderna, o que passou a importar foi o fundamento simples, horizontal e imóvel do fato físico do corpo: o sexo ${ }^{13}$.

Ainda segundo esse historiador, até o século XIX, os modelos culturais se apoiavam na ideia aristotélica de inferioridade do gênero feminino, uma concepção na qual a causa material era inferior à causa eficiente. Nesta, não havia a necessidade dos fatos da diferença sexual para fundamentar a diferença dos gêneros, ou seja, apesar da afirmação de que a geração do macho era a causa eficiente e a da fêmea a causa material não ser fisicamente demonstrável, reforçava o que significava ser homem e mulher, de modo que a natureza do sistema reprodutor era apenas incidental para definir as diferenças sexuais nos grupos humanos. Assim, o ventre, identificado como 'falo negativo' durante o século XVIII, tornou-se o 'útero' - um órgão cuja anatomia e fisiologia ofereciam uma explicação científica para a condição social da mulher. Todavia, era o contexto político do período que influenciava a articulação da incomensurabilidade dos sexos. Com efeito, havia muitas lutas pelo poder entre homens e mulheres, sobretudo a partir do século XIX. Assim, quando

a ordem transcendental preexistente ou os costumes de tempos imemoriais tornaram-se cada vez menos uma justificativa plausível para as relações sociais, o campo de batalha do gênero mudou para a natureza, para o sexo biológico ${ }^{13(192)}$.

Portanto, esse é o ponto no qual as diferenças anatômicas passaram a ser utilizadas para sustentar ou impedir reivindicações sociais, políticas, econômicas, culturais e/ ou eróticas; e o corpo tornou-se o padrão ouro para todos os assuntos.
A construção da incomensurabilidade dos sexos não foi obra do século XVIII, mas começou no século XVII e culminou na publicação de obras científicas em que se podia encontrar argumentos explicitamente construídos apoiando os fundamentos biológicos de uma ordem moral. Com efeito, os cientistas do período forneceram seus dados e prestígio às ideologias dominantes, ao descobrirem ou comprovarem os aspectos da diferença sexual que haviam sido ignorados até então. Além disso, a política de gênero implementada nessa época afetou a interpretação e a produção de dados clínicos e laboratoriais. Assim, tais diferenças sexuais produzidas pelo avanço científico e interpretadas pelos vieses cultural e político modernos foram as bases para a construção da incomensurabilidade dos sexos, isto é, a afirmação de que existem dois sexos que são anatômica, biológica, genética, embriológica e fisiologicamente diferentes, que perdura até os dias atuais ${ }^{13}$.

Curiosamente, mesmo com as contradições encontradas nos estudos da embriologia, a evolução de instrumentos como o microscópio e a consequente identificação dos gametas no século XIX contribuíram ainda mais para que o sexo fosse assimilado à cultura. Efetivamente, houve uma corrida para encontrar a reprodução sexual em todos os seres vivos, inclusive nas plantas, que passaram a ter gênero e cuja natureza sexual tornou-se a base para o sistema de classificação de Lineu. Os filósofos da natureza do período pareciam ter razão em considerar a diferença sexual uma das dicotomias fundamentais da natureza, um abismo intransponível nascido dos próprios germes reprodutivos e dos órgãos que os produziam ${ }^{13}$.

Neste ponto, vale dizer que a cientista social Fabíola Rohden traz uma importante contribuição para a percepção da metáfora do sangue nas ideias sobre as diferenças entre os sexos ao comentar sobre os desenvolvimentos científicos contemporâneos que ligam os hormônios, particularmente os sexuais, ao bem-estar, à saúde e a determinados comportamentos, aprofundando tais diferenças no âmbito do 
saber biomédico. Segundo ela, atualmente há o predomínio de um império do "'corpo hormonal' que parece se sobrepor a qualquer outra concepção biomédica corrente"15(134). Sendo assim, e se a aproximação for pertinente, é possível inferir que, no paradigma bioquímico do 'corpo hormonal', a metáfora do sangue se mistura à compreensão de que o corpo da mulher fica à mercê dos ciclos hormonais relacionados com a sua atividade reprodutiva em potencial, desde a puberdade até a menopausa, tanto em condições fisiológicas quanto patológicas ${ }^{15}$, o que, por conseguinte, confere subsídios ‘científicos' para o desenvolvimento de dispositivos institucionais, e porque não dizer biopolítico-imunitários, para o controle do gênero feminino.

Com efeito, se pelo menos até o final do século XIX era nítida a busca de um órgão que justificasse a diferença entre homens e mulheres, já no início do século XX, o desafio era entender como as substâncias produzidas pelas gônadas e veiculadas pela circulação sanguínea operariam o processo de diferenciação, fundamental na construção dos dispositivos sociais de controle nesse período. Se antes o ovário poderia ser visto como 'centro condensador da feminilidade', assim como o testículo o era para a masculinidade, agora se tratava de descobrir o mecanismo de produção da própria feminilidade e da masculinidade nos fluidos corporais. Em outros termos, o paradigma bioquímico de causa e efeito passou a determinar o que se deveria procurar e até aonde as explicações deveriam chegar16. Foi nesse contexto de busca pelas causas últimas dos fenômenos e de marcada relação entre sexo físico-corporal, estereótipos de gênero e identidades sexuais substancializada em órgãos e agora em secreções internas propagadas pelo sangue, que se descobriram os chamados hormônios sexuais.

Efetivamente, na literatura científica das primeiras décadas do século XX, havia uma correlação entre os planos anatômico e moral que se traduzia na redução das condutas individuais às causas orgânicas, mais especificamente bioquímicas, em última análise perpassadas pela metáfora do sangue. Assim, o discurso sobre o corpo da mulher não era somente a descrição fisiológica do corpo feminino, mas também um tratado moral sobre sua conduta fundamentado nas características bioquímicas inerentes ao seu próprio sangue. Em outros termos, o argumento das diferenças sexuais contaminado pela metáfora do sangue e produzido pelo avanço científico do início do século passado foi interpretado pelo viés cultural e político se tornando a base para noção da incomensurabilidade dos sexos que ainda hoje influencia moralmente a sociedade ${ }^{13,15}$.

\section{Corpo e território}

Tendo clarificado esse ponto e retornando à preocupação ocidental com o corpo, torna-se agora compreensível porque esta entidade obteve uma nova importância no século XVIII e seguintes já que se tornou a origem e o destino das dinâmicas sociopolíticas e o padrão ouro do discurso científico, social e moral modernos 1,10,16,17, paralelamente à redução epistemológica do cosmo à nature$\mathrm{za}^{13} \mathrm{e}$ à identificação do homem a um corpo estável e a-histórico.

No início do século XX, a popularização das descobertas genéticas contribuiu ainda mais para o reforço do corpo no registro científico. Concebido como um complexo bioquímico inextricável e variável ${ }^{18}$, fonte das gerações e degenerações, ele se transformou em um carreador de 'genes'10, saúde, doença, moral e vício. Não havia ainda a concepção atual dos 'genes', que tinha mais relação com os aspectos caracterológicos, morais e étnicos associados à hereditariedade (ao genus). Assim, o corpo se tornou um veículo difusor tanto dos 'genes' quanto dos germes, isto é, do 'sangue' e de bactérias. É importante frisar novamente esse ponto pelo fato de que o deslocamento das massas pelos espaços e a influência do meio sobre a saúde do indivíduo passaram a ser fontes de muitas inquietações sanitárias 
e biopolíticas ${ }^{16}$. Com efeito, a intensificação do tráfego entre o Velho Mundo e suas ex-colônias, principalmente em virtude do afluxo de imigrantes aos novos Estados-Nação, promoveu um maior desenvolvimento de tecnologias de controle de circulação, resguardo das fronteiras e de vigilância da saúde. Dessa forma, saúde pública e nacionalismo se vinculavam ao projeto de modernização que incluía também um território definido, uma política econômica, uma democracia liberal e a ideia de cidadania $8,19,20$.

Em uma metáfora orgânica semelhante à de Hobbes em 'Leviatã' (1651), o território equivale ao corpo do Estado-Nação e, nesse sentido, o território nacional é definido pelo recurso dos mapas. A territorialidade é o 'mais que isso' que envolve a ideia de um coletivo humano fundante das referências social, cultural, histórica e econômica desse território; isto é, da nação. Assim, a nação é fonte de soberania e de legitimidade do Estado que existe como um 'corpo nacional' intangível e cuja integridade depende desse respectivo coletivo humano. Em outros termos, nas teorias espaciais que se desenvolveram entre os séculos XIX e XX, os grupos humanos que fundamentavam o Estado necessitavam estar referenciados a um território específico para existir politicamente. O Estado seria intangível porque existiria no papel como uma ilustração com pretensão de realidade, e sua integridade dependeria do coletivo que sustentaria essa pretensão por meio dos artifícios (instituição, leis, representatividade governamental) desenvolvidos para o seu estabelecimento e manutenção, o que garantiria sua legitimidade.

Assim, esse Estado-organismo é como um 'espaço vital' que funcionaria como mediador entre o povo e o solo. Nessa mediação, o povo participaria com o sentimento de pertencimento territorial obtido a partir de sua ligação permanente com o solo, sua região ou seu país. Tal 'espaço vital' é inicialmente vinculado à ideologia do Lebensraum de Ratzel, mas que, por extensão, abrange também o 'mundo da vida' (Lebenswelt) ${ }^{\mathbf{2 1}}$. Na teoria de Ratzel, a política se articulava com o espaço e introduzia a noção de 'sentido de espaço' segundo a qual determinados grupos humanos possuíam uma capacidade superior de ordenamento das paisagens e da valorização de seus recursos naturais, assim como de se fortalecer por meio de sua fixação e enraizamento em um dado território. O modelo de Lebensraum de Ratzel tem conexões com o saber biológico desenvolvido no mesmo período, e seus temas de eleição harmonizavam-se com as grandes questões da época tais como as disputas territoriais e o fortalecimento nacional como garantia de poder dos povos sobre os territórios ocupados ${ }^{22}$.

Em outras palavras, a delimitação de um território nacional era questão fundamental para a horogênese ${ }^{23}$ dos Estados modernos ${ }^{24}$. Assim, o limite abstrato entre os Estados se materializava nos dispositivos biopolíticos criados para o controle das bordas de seus respectivos 'geo-corpos', um artifício utilizado para a definição territorial e que afeta pessoas, coisas e relações ${ }^{19,25}$. Logo, a delimitação das fronteiras passou a ser prioridade, e a institucionalização da quarentena marcou a transformação desses locais em um espaço administrativo com funções sanitária, militar, política e econômica' ${ }^{19}$. Em particular, a quarentena se mostraria um dispositivo biopolítico que indicava como um país se definia e como se concebia seguro ${ }^{19}$. Em acréscimo, ela imputaria ao migrante o ônus de ocupar um lugar ambíguo no qual era integrado por sua força de trabalho e excluído pelo nativismo nacionalista ${ }^{8}$, traço marcante do paradigma da imunização ${ }^{6}$.

Quanto à noção de geocorpo, esta remonta ao conceito medieval de dois corpos do rei que evoluiu para a metáfora do Estado como um organismo político/social no qual os corpos do homem e do cidadão se conjugariam e funcionariam complementarmente em um todo ${ }^{10}$. $O$ geocorpo é descrito como uma definição territorial artificial produtora de uma cadeia de efeitos nas pessoas, coisas e relações ${ }^{19,25}$. Nele, o imaginário é a base para a sedimentação do referencial político e simbólico das identidades 
coletivas nacionais ${ }^{21}$. Isto é, este termo inaugura uma representação de mundo, incluindo a sociedade mesma e seu lugar nele, que ultrapassa o constructum intelectual, porque ligada à intenção coletiva de uma dada sociedade e à Stimmung que embebe a totalidade da vida social ${ }^{26}$. Portanto, a tradução dos limites geográficos em discurso e o consequente reforço desse discurso das identidades coletivas nacionais, isto é, do Estado-Nação, mediante representações e dispositivos administrativos biopolíticos, promoveram parcialmente a metamorfose da geografia de nações, como, por exemplo, a Austrália, entre o final do século XIX e as primeiras décadas do século $\mathrm{XX}^{19}$.

Naquele país, assim como em outros Estados-Nação, as metáforas biomédicas microbiológicas desse período, sinergicamente à metáfora do sangue, serviram de fundo para o âmbito da ação política. Tem-se então que a biopolítica articulada ao conhecimento sobre a imunidade indicava a necessidade crescente de proteção do território australiano sob fluxo migratório intensivo ${ }^{\mathbf{1}, 14}$. Assim, a articulação entre o discurso biomédico sobre epidemia, contágio, imunidade e higiene e o da defesa nacional sobre resistência, proteção, invasão e imigração reforçava a institucionalização da quarentena como um tipo de dispositivo biopolítico de proteção territorial contra a contaminação representada pelos movimentos migratórios, isto é, contra o perigo da contaminação do sangue australiano com o sangue estrangeiro. Nesse sentido, a fronteira australiana ilustra as ideias baseadas em pureza e vulnerabilidade do sangue nacional, e se comportava como local de regulação comercial e moral, além do controle médico-legal ${ }^{19}$.

Essa preocupação com as fronteiras também surgiu em países como os Estados Unidos que não tinham um limite territorial facilmente definido pela geografia como a Austrália. O caráter imaginário de seu limite com o México se modificou ao longo dos eventos que acompanharam as transformações dos padrões de migração e dos dispositivos biopolíticos entre o final do século XIX e o início do XX.
A mudança nas políticas migratórias norte-americanas aplicadas sobre determinados povos até fins do século XIX concentrou-se sobre a população mexicana a partir dos anos 1920, culminando no Ato Nacional das Origens de 1924 e na instituição da guarda de fronteira ${ }^{8}$. Aqui, o termo 'sangue' se torna novamente uma pista para a compreensão dos dispositivos biopolíticos, e sua polissemia indica tanto a origem e a cultura de grupos humanos como o veículo de germes e de 'genes', no caso a 'raça'. Esse termo está de acordo com os censos e indexadores norte-americanos dos fins do século XIX e primeiras décadas do XX, e se refere ao passado, à história e à herança dos povos, prestava-se para a divisão da população em subgrupos, o estabelecimento de um corte biológico e uma espécie de hierarquia entre eles. Na categoria 'mexicano' ilustrada por Stern, por exemplo, o censo norte-americano de 1930 combinava a noção de 'raça' à de 'nação' e exemplifica o que se entende como metáfora do sangue, devendo ser visto sob esta perspectiva ao longo de todo este trabalho ${ }^{8}$.

Vale ainda dizer que se considerarmos a possibilidade de a polissemia do termo 'sangue' se amplificar a partir do limite do corpo individual ou da identidade grupal e se ligar à ideia de Estado-Nação como geocorpo, a noção de fronteira sofre uma profanação, isto é, um deslocamento ${ }^{27}$. Destarte, os limites nacionais abandonam a concepção usual de fronteira, ganham capilaridade e se movem reversivelmente da paisagem geográfica da nação para a epiderme dos cidadãos, bem como do corpo individual dos imigrantes para seus respectivos grupos e culturas ${ }^{8}$. Em outras palavras, as fronteiras dos países se condensam simbolicamente nos limites dos corpos individuais; e o conjunto destes - o corpo social - se dilata e se comuta em um dos aspectos do geocorpo. Fenômenos como esse embasaram as metáforas político-imunitárias de proteção e fortificação das bordas nacionais a partir da tese médica de defesa do organismo ante o perigo de contaminação $0^{5}$, assim como deve também servir de modelo para a compreensão deste trabalho. 
Efetivamente, o desenvolvimento do paradigma da imunização adveio parcialmente da conscientização da existência de ameaças internas e externas às sociedades modernas e em benefício do corpo social e da integridade de seus membros ${ }^{1,14}$. Ele conjuga simultaneamente biopolítica e modernidade e demonstra como os dispositivos biopolíticos criados para proteger a vida e as subjetividades, paradoxalmente, produzem restrições e extermínios ${ }^{\mathbf{1}, \mathbf{6}}$.

Em resumo, a partir do artifício da metáfora do sangue, pode-se depreender que a 'autoconservação imunitária'6 marcou o desenvolvimento australiano ${ }^{19} \mathrm{e}$ norte-americano ${ }^{8}$, entre outras nações, em graus e modos diferentes de implementação, bem como a construção da família medicalizada e da maternidade científica, ambos produtos do projeto modernizador brasileiro como se verá a seguir.

\section{Corpo, paradigma da imunização e eficiência nacional}

Como projeto modernizador das ex-colônias, o paradigma da imunização não considerava imigrantes e minorias como cidadãos, mas como alvos de medidas higiênicas verticalizadas ${ }^{29}$. A estigmatização étnica e social estava relacionada com a busca do tipo ideal de cidadão: saudável, trabalhador e obediente. Tal indivíduo provinha da família medicalizada, uma espécie de garantia da eficiência nacional, isto é, da viabilidade da nação ${ }^{\mathbf{1 4}, \mathbf{1 9}}$. No conjunto da valorização social das ciências, a biologia da incomensurabilidade trazia a ideologia da maternidade atrelada ao projeto nacionalista ${ }^{16}$. Forjando um discurso pautado na higiene, em que convergiam noções de saúde, educação e patriotismo, os dispositivos biopolíticos voltavam-se para a proteção tanto do território nacional como do 'território privado', da vida doméstica, particularmente por meio do papel das mulheres ${ }^{14,28}$.

No Brasil, por exemplo, a Proclamação da República inaugurou um período de reorganização dos sentidos dados à nação no qual houve a necessidade da redefinição do povo, de uma cidadania e de sua representação, em suma, de seu sangue. A nação passou a ser debatida não só entre a elite letrada, mas também a fazer parte do projeto político estatal $^{30}$. A medicina higienista era a maior aliada no combate à doença e no desenvolvimento da identidade nacional ${ }^{31}$. Muitos sanitaristas aderiam a uma 'eugenia preventiva' nos moldes da medicina social francesa, provavelmente porque os limites entre eugenia e higiene eram imprecisos e ambos os termos tinham caráter prospectivo e de melhoramento nacional. Nomes importantes como Renato Kehl e Edgard Roquette-Pinto, apesar de suas divergências quanto à concepção de eugenia, pautavam a reforma da sociedade, o aperfeiçoamento racial e a solução da 'questão social' nas descobertas biomédicas de então ${ }^{18}$.

Renato Kehl (1889-1974) era adepto da 'eugenia negativa', que adotava medidas radicais de controle matrimonial, esterilização e políticas de segregação racial e social, além de associar os problemas brasileiros à constituição biológica dos ‘tipos nacionais'. Estes foram produtos do esforço e mobilização de médicos, naturalistas, antropólogos e cientistas de fins do século XIX e início do século XX para a caracterização das populações humanas que compunham a sociedade brasileira, sua 'constituição racial' e sua diversidade biológica, com o objetivo de construir um panorama das 'raças humanas' por meio de classificações morfoanatômicas das partes do corpo ${ }^{32}$. Por sua vez, Edgard Roquette-Pinto (1884-1954) defendia a perfectibilidade eugênica dos 'mestiços do Brasil' e empregava a antropologia física para negar o determinismo racial defendido pelos eugenistas negativos ${ }^{\mathbf{1 8}}$. Ligava-se sobretudo à 'eugenia positiva' que focava o desenvolvimento e emprego de medidas educativas e de aconselhamento eugênico segundo a proposta galtoniana. Tal proposta partia da noção de que a perpetuação de características degenerativas na média populacional era a maior responsável pela manutenção das situações 
sociais adversas, ou seja, procurava a origem das mazelas sociais nos traços ou características individuais 'inatas' ${ }^{33}$. Nesse contexto, pode-se depreender que as ideias relacionadas com a constituição racial e com a diversidade biológica do brasileiro também estavam fundamentadas em metáfora do sangue, sendo este fluido o principal carreador das características individuais e dos grupos humanos.

Nesse cenário de um Brasil preocupado com a identidade nacional nas primeiras décadas do século XX, a maternidade extrapolou o âmbito da vida privada e contribuiu para a concepção da mulher como produtora de cidadãos ${ }^{16}$ ao se vincular ao projeto republicano a partir de uma outra concepção da missão feminina, qual seja: a de 'melhorar o sangue' nacional e produzir cidadãos para a Pátria. Assim, o projeto nacionalista brasileiro construiu políticas públicas voltadas para a proteção social das mães e dos filhos e reforçou o movimento maternalista, contribuindo para transformar a maternidade em valor social e dever patriótico ${ }^{28}$.

Foi pensando nesse novo ideário que a práxis médica brasileira reforçou seu poder disciplinador sobre os corpos femininos a partir da introdução da biotecnociência em seu discurso e promovendo uma mudança do modelo de maternidade tradicional para a 'maternidade científica', ou seja, a produção de uma mãe moderna, isto é, uma maternidade que demandava um conhecimento específico suprido pelo discurso científico e por novos dispositivos de biopoder baseados na pedagogia dos corpos.

Apesar da medicina social francesa estender seu lastro de influência sobre o Brasil, foram os argumentos morais e culturais associados aos projetos feministas e aos imperativos nacionalistas, tais como a defesa da maternidade como dever nacional, que prevaleceram por aqui. Somando-se a isto, a ameaça à construção da nação representada pela precariedade das condições sanitárias e pela alta mortalidade infantil foi motivo suficiente para justificar o ataque às tradições culturais e a adoção da ciência como principal aliada do poder. Nesse contexto, a maternidade científica brasileira era simultaneamente produto da natureza feminina, missão divina e dever social, e o papel de mãe incorporava tanto uma missão patriótica, prezar o 'sangue nacional', como uma prática científica ${ }^{28}$. Assim, a amamentação também saiu do escopo das atividades femininas possíveis para se tornar missão patriótica, submetida à racionalidade médica e explicada segundo os cânones higienistas. Por outro lado, embora fosse grande o aporte científico e racional utilizado para justificar $\mathrm{o}$ aleitamento, os principais argumentos eram explicitamente morais e religiosos ${ }^{28}$.

Com efeito, a ideologia higienista de gênero do período girava, sobretudo, em torno das atividades domésticas. Pode-se depreender de seu discurso que a metáfora do sangue, traduzida no medo do contágio e no perigo dos germes, fundamentou a produção de um conjunto de práticas domésticas ritualizadas avalizadas pela ciência e identificadas como femininas e modernas. Dessa forma, é possível compreender que a produção da maternidade científica e da medicalização da criação dos filhos por meio da produção de dispositivos biopolítico-imunitários e a partir da metáfora do sangue sedimentou a concepção da casa como lugar de exercício biopolítico do poder ao mesmo tempo em que conferiu o status de atividade científica aos afazeres cotidianos da mulher.

\section{Considerações finais}

Este trabalho pretendeu utilizar a metáfora do sangue como chave heurística e referencial na análise para a compreensão do Estado-Nação no final do século XIX e nas primeiras décadas do século XX, o que pode contribuir para a problematização dos dispositivos biopolítico-imunitários envolvidos na construção identitária nacional. Nesse sentido, procurou-se ilustrar como os discursos biomédico, científico, político e moral se misturaram e se confundiram durante a formação de países como Austrália, Estados Unidos e Brasil, fundamentando um 
amplo conjunto de comportamentos, crenças e saberes difundidos pelos meios científicos, políticos e sociais, o que pode ter favorecido a naturalização de ideologias nacionalistas.

Por conseguinte, a polissemia do termo 'sangue' no final do século XIX e no início do século XX deu origem à metáfora do sangue detectada no discurso dominante do paradigma da imunização ilustrado neste trabalho por meio da construção do discurso científico da incomensurabilidade dos sexos, bem como da 'autoconservação imunitária' 6 australiana ${ }^{19}$ e norte-americana ${ }^{8}$, além de fundamentar a produção da família medicalizada e da maternidade científica no âmbito do projeto modernizador brasileiro, o que corrobora o poder de capilarização da metáfora do sangue em se imiscuir e abarcar dimensões relativas tanto à noção de território e nação quanto àquelas dos âmbito da vida privada.

Finalmente, buscou-se mostrar que os dispositivos biopolíticos e de biopoder são capazes de se entranhar na agenda medicalizante e higienista dos projetos modernos de nação desde a vida doméstica até os limites geopolíticos quando são vistos por meio da metáfora do sangue. Associada à noção de corpo, a metáfora do sangue trouxe ao termo 'fronteira' um alto grau de capilaridade, o que lhe permitiu romper com seu significado tradicional e se projetar na dimensão da vida humana, o locus de ação biopolítica. Por fim, em nosso entendimento, este artifício pode contribuir para a compreensão de um dos aspectos do paradigma da imunização relacionado com o estabelecimento do EstadoNação no final do século XIX e nas primeiras décadas do século XX, qual seja, a criação de dispositivos biopolíticos para a eliminação de ameaças internas e externas às sociedades em benefício do reforço de seu corpo social e da integridade de seus membros.

\section{Colaboradores}

Rodrigues CAB (0000-0002-4163-0661)* e Schramm FR (0000-0001-6291-3188)* contribuíram igualmente para a elaboração do manuscrito.

\section{Referências}

1. Radomsky GFW. Roberto Esposito: comunidade, biopolítica e imunização. Política \& Sociedade [internet]. 2017 [acesso em 2018 mar 29]; 16(35):459-473. Disponível: https://periodicos.ufsc.br/index.php/politica/article/view/2175-7984.2017v16n35p459.

2. Foucault M. A política da saúde no século XVIII. In: Foucault M. Microfísica do poder. Rio de Janeiro: Graal; 2006. p. 193-207.
3. Foucault M. Aula de 17 de março de 1976. In: Foucault M. Em defesa da sociedade: Curso no Collège de France (1975-1976) [internet]. São Paulo: Livraria Martins Fontes Editora Ltda; 1999, p. 285-315. (Coleção Tópicos). [acesso em 2018 jul 26]. Disponível: http://petdireito.ufsc.br/wp-content/uploads/2016/05/Foucalut-M.-Em-defesa-da-sociedade. pdf.
*Orcid (Open Researcher and Contributor ID). 
4. Castro E. Biopoder. In: Castro E. Vocabulário de Foucault. Belo Horizonte: Autêntica; 2009. p. 57-59.

5. Nalli MAG. A abordagem imunitária de Roberto Esposito: biopolítica e medicalização. Revista Internacional Interdisciplinar INTERthesis [internet]. 2012 [acesso em 2018 mar 23]; 9(2):39-50. Disponível: https://periodicos.ufsc.br/index.php/interthesis/article/view/27319.

6. Nalli MAG. Communitas/Immunitas: a releitura de Roberto Esposito da biopolítica. Revista de Filosofia Aurora [internet]. 2013 [acesso em 2018 mar 29]; 25(37):79-105. Disponível: https://periodicos.pucpr. br/index.php/aurora/article/view/580.

7. Esposito R. O paradigma da imunização. In: Esposito R. Bios: Biopolítica e filosofia. Belo Horizonte: Editora UFMG; 2017, p. 59-98.

8. Stern AM. Buildings, Boundaries, and Blood: Medicalization and Nation-Building on the U.S.-Mexico Border, 1910-1930. Hisp Am Hist Review. 1999; 79(1):41-81.

9. Sontag S. A doença como metáfora. Rio de Janeiro: Graal; 1984. (Tendências, 6).

10. Souki N. A metáfora hobbesiana do corpo e o biopoder. Filosofia [internet]. 2016 [acesso em 2018 mar 23]; 33:261-271. Disponível: http://pentaho.letras up.pt/index.php/filosofia/article/view/3369/3081.

11. Merleau-Ponty M. O corpo como expressão e a fala. In: Merleau-Ponty M. Fenomenologia da percepção. São Paulo: Editora Perspectiva; 2011. p. 237-278.

12. Foucault M. Soberania e disciplina. In: Foucault M. Microfísica do poder. 22. ed. Rio de Janeiro: Edições Graal; 2006. p. 179-191.

13. Laqueur T. A descoberta dos sexos. In: Inventando o Sexo: corpo e gênero dos Gregos a Freud. Rio de Janeiro: Relume Dumará; 2001. p. 189-240.

14. Pabón ACB, Collazos WP. Conservación de la salud del cuerpo como estrategia de vigilancia y control del derecho en lo concerniente a lo higiénico y sanita- rio desde las reformas borbónicas. Revista Prolegómenos - Derechos y Valores [internet]. 2011 [acesso em 2018 mar 18]; 14(27):231-245. Disponível: https:// dialnet.unirioja.es/servlet/articulo? codigo $=3699271$.

15. Rohden F. O império dos hormônios e a construção da diferença entre os sexos. História, Ciência, Saúde. 2008; 15(supl1):133-152.

16. Rohden F. A construção da diferença sexual na medicina. Cad Saúde Pública [internet]. 2003 [acesso em 2018 mar 18]; 19(supl2):S201-S212. Disponível: www.scielo.br/pdf/\%0D/csp/v19s2/a02v19s2.pdf.

17. Foucault M. Poder - Corpo. In: Foucault M. Microfísica do poder. Rio de Janeiro: Graal; 2006. 145-152.

18. Souza VS. A eugenia brasileira e suas conexões internacionais: uma análise a partir das controvérsias entre Renato Kehl e Edgard Roquette-Pinto, 1920-1930. História, Saúde. 2016; 23(supl1):93-110.

19. Bashford A. Quarantine: Imagining the geo-body of a nation. In: Bashford A. Imperial Hygiene: A Critical History of Colonialism, Nationalism and Public Health [internet]. London: Palgrave MacMillan; 2004. p. 115-136. [acesso em 2017 mar 21]. Disponível: http:// graduateinstitute.ch/files/live/sites/iheid/files/sites/ $\mathrm{mia} / \mathrm{shared} / \mathrm{mia} /$ cours/IA023/Week\%204/Bashford Imperial_Hygiene_A_Critical_History_of_Colonialism_Nationalism_and_Public_Health.pdf.

20. Ortiz R. Imagens do Brasil. Revista Sociedade e Estado [internet]. 2013 [acesso em 2018 mar 16]; 28(3):609633. Disponível: http://www.scielo.br/pdf/se/v28n3/ a08v28n3.pdf.

21. Magnoli D. O corpo da pátria: Imaginação geográfica e política externa no Brasil (1808-1912). São Paulo: Ed. UNESP; 1997.

22. Arcassa WS, Mourão PFC. Karl Haushofer: A Geopolitik alemã e o III Reich. GeoAtos - Revista Geografia em atos, Presidente Prudente [internet]. 2011 [acesso em 2018 ago 30]; 1(11):1-14. Disponível: http:// revista.fct.unesp.br/index.php/geografiaematos/article/view/249/arcassa. 
23. Cerri LF, Magnoli D. O corpo da pátria - imaginação geográfica e política externa no brasil (1808-1912). São Paulo: Moderna. Revista de História Regional [internet]. 1998 [acesso em 2018 mar 14]; 3(2):181-185. Disponível: www.revistas2.uepg.br/index.php/rhr/article/view/2069/1551.

24. Esteves C. O território brasileiro e a formação nacional: algumas aproximações a partir da produção intelectual no Brasil. GOT [internet]. 2014 [acesso em 2018 mar 6]; 6:89-111. Disponível: http://www.scielo.mec.pt/scielo.php?script=sci_arttext\&pid=S2182$-12672014000200007 \& \operatorname{lng}=$ pt\&nrm=iso.

25. Winichakul T. Introduction: The presence of Nationhood. In: Winichakul T. Siam Mapped: A History of the Geo-Body of a Nation. University of Hawaii Press [internet]. 1994. p. 1-19. [acesso em 2018 maio 19]. Disponível: http://www.univpgri-palembang. ac.id/perpus-fkip/Perpustakaan/Politik/Siam\%20 Mapped,\%20A\%20History\%20of\%20the\%20Geo-Body\%20of\%20a\%20Nation.pdf.

26. Castoriadis C. El imaginario social instituyente. Zona Erógena. [internet]. 1997 [acesso em 2018 mar 16]; 35:1-9. Disponível: http://www.ubiobio.cl/miweb/ webfile/media/267/Castoriadis\%20Cornelius\%20-\%20El\%20Imaginario\%20Social\%20Instituyente. pdf.

27. Agamben G. Elogio da profanação. In: Agamben G. Profanações. São Paulo: Boitempo; 2007. p. 65-80.

28. Freire MML. 'Ser mãe é uma ciência': mulheres, médicos e a construção da maternidade científica na década de 1920. História, Ciência, Saúde. Rio de Janeiro: 2008 ; 15(supl1):153-171.
29. Di Liscia MS. Desde fuera y desde dentro: Enfermidades, etnias y nación (Argentina, 1880-1940). In: Hochman G, Di Liscia MS, Palmer S, organizadores. Patologías de la Patria: Enfermedades, enfermos y nación en América Latina. Buenos Aires: Lugar Editorial; 2012. p. 124-153.

30. Carvalho NR. Natureza, território, civilização e modernidade e a construção da nação nos livros didáticos de geografia da Primeira República. Geo Ens Pesq [internet]. 2016 [acesso em 2018 mar 16]; 20(2):7894. 2016. Disponível: https://periodicos.ufsm.br/geografia/article/view/17755.

31. Lima NT, Hochman G. "Condenado pela raça, absolvido pela medicina": o Brasil descoberto pelo movimento sanitarista da Primeira República. In: Maio MC, Santos RV, editores. Raça, ciência e sociedade. Rio de Janeiro: Fiocruz; CCBB; 1996. p. 23-40.

32. Souza VS, Santos RV. Corpos, medidas e nação: antropologia física na capital da República brasileira na primeira metade do século XX. Bol. Mus. Para. Emílio Goeldi. Ciênc. hum. Belém [internet]. 2012 [acesso em 2019 jan 11]; 7(3):639-643. Disponível: http://www. scielo.br/scielo.php?script=sci_arttext\&pid=S1981$-81222012000300002 \& \operatorname{lng}=\mathrm{en} \& \mathrm{nrm}=$ iso.

33. Del Cont V. Francis Galton: eugenia e hereditariedade. Sci. stud. [internet]. 2008 [acesso em 2019 jan 11]; 6(2):201-218. Disponível: http://www.scielo.br/scielo.php?script=sci_arttext\&pid=S1678$-31662008000200004 \& \operatorname{lng}=\mathrm{en} \& \mathrm{nrm}=$ iso.

Recebido em 21/02/2019

Aprovado em 31/10/2019

Conflito de interesses: inexistente

Suporte financeiro: não houve 